\title{
Assessment of Groundwater Quality Changes in the Rural Environment of the Hungarian Great Plain Based on Selected Water Quality Indicators
}

\author{
Tamás Mester [D D Dániel Balla • György Szabó
}

Received: 8 July 2020 / Accepted: 16 October 2020 / Published online: 22 October 2020

(C) The Author(s) 2020

\begin{abstract}
In the present study, changes in groundwater quality are assessed after the construction of the sewerage network, based on 3 water quality indices. Sampling took place before (2013) and after $(2017,2018,2019)$ the establishment of a sewerage network in 2014. In the pre-sewerage period, strong pollution of the groundwater was detected. A total of $90 \%$ of the groundwater wells according to the water quality status by Brown, $70 \%$ of the wells according to the contamination index $\mathrm{C}_{\mathrm{d}}$ by Rapant, and $80 \%$ of the wells according to the Canadian Council of Ministers of the Environmental Water Quality Index were categorized in the "polluted" or "heavily polluted" categories. After the establishment of the sewerage, significant changes were observed. In 2017 , the number of wells in category 5 indicating the most contaminated samples decreased significantly for all three indices, while the number of samples in categories "good" and "acceptable" increased. Discriminant analysis was performed to determine if pre- and postsewerage samples could be separated. A total of $75.6 \%$ of the cross-validated values were successfully categorized into the appropriate category, which indicates a significant difference between pre- and post-sewerage. Based on point and interpolated maps, it was established
\end{abstract}

T. Mester $(\bowtie) \cdot$ G. Szabó

Department of Landscape Protection and Environmental Geography, University of Debrecen, Debrecen, Hungary e-mail:mester.tamas@science.unideb.hu

D. Balla

Department of Computer Graphics and Image Processing, University of Debrecen, Debrecen, Hungary that in 2013, all three indices showed the highest pollution in the inner and southern parts of the settlement, while the northern areas of the settlement were less polluted. Based on the indices, it was determined that the process of groundwater purification in the settlement has started, although it will continue for years to come.

Keywords Water quality index · Groundwater quality · Pollution $\cdot$ Wastewater $\cdot$ Cleaning process

\section{Introduction}

Assessment of groundwater quality is critical for resource planning and environmental management (Mohamed et al. 2019). Since water quality status can be described by a number of physical, chemical, and biological parameters, large amounts of data make assessment and comparison significantly difficult (Reisenhofer et al. 1998). The most important benefit of water quality indices (WQI) is to provide a simplified approach for the assessment of water quality by greatly minimizing the data volume and simplifying the expression of water quality status (Al-Omran et al. 2018). Thus, the use of these indices in ecosystem monitoring programs makes it possible to inform the general public and decision-makers about the state of the environment (Tiwari et al. 2016; Venkatramanan et al. 2017; Bilgin 2018; Wu et al. 2020). This approach can also help to provide a benchmark for evaluating the successes and failures of management strategies in improving water quality, and it will also indicate what actions should be 
modified (Katyal 2011). Thematic maps based on water quality indices provide a comprehensive picture of a given environmental problem and are easily understood by those outside the scientific field (Stigter et al. 2006). Thus, the use of water quality indices has become a common practice in describing the status of surface and groundwater (Liou et al. 2004; Espejo et al. 2012; Bora and Goswami 2017; Bouslah et al. 2017; Jha et al. 2020).

However, water quality varies according to the type of use; therefore, acceptable water quality criteria depend upon the characteristic conditions, and these vary from time to time and from region to region. The time of sampling also significantly influences water quality parameters and hence the index value. However, it is extremely difficult to develop a universally acceptable general water quality index (Poonam et al. 2013).

After Horton's first WQI (1965), numerous indices have been developed in the past decades which display water quality in a single value by comparing different parameters as per the standards. Such indices are the US National Sanitation Foundation Water Quality Index (NSFWQI) (Sharifi 1990), the Canadian Council of Ministers of the Environment Water Quality Index $\left(\mathrm{CCME}_{\mathrm{wqi}}\right)$ (Lumb et al. 2006), the British Columbia Water Quality Index (BCWQI), the Oregon Water Quality Index (OWQI) (Abbasi 2002; Debels et al. 2005; Kannel et al. 2007), and the weighted average WQI developed by Brown et al. (1970).

Brown et al. (1970) suggested a multiplicative form of the index, where the weight of each parameter was created according to the subjective opinion of the author, based on the given research. The weight assigned to a given parameter (which reflects the significance of the parameter for a given use) has a significant effect on the index. The $\mathrm{CCME}_{\mathrm{wqi}}$ compares observation values to a benchmark instead of normalizing observed values to subjective rating curves, where the benchmark may be a water quality standard or site-specific background concentration (CCME 2001; Khan et al. 2003; Lumb et al. 2006). Therefore, this is an advantage of the index, which can be applied by water agencies in different countries with little modification.

Various water quality indices have been examined in several studies, which state that almost all water quality indices depend upon normalizing data by parameter, according to expected concentrations and the interpretation of "good" versus "bad" concentrations (Liou et al. 2004). Pesce and Wunderlin (2000) concluded in their study that the water quality indices examined were generally correlated with the measured concentrations of different parameters. Štambuk-Giljanović (1999) also used different WQIs for the assessment of Dalmatian surface and groundwater supplies. They found that modified arithmetic indices were best suited for discriminating sites according to their water quality condition.

Many studies use different indices to analyze water quality. Backman et al. (1998) carried out a water quality classification in the interior areas of southwestern Finland and Slovakia, where the practicability of the pollution index developed by Rapant et al. (1995) was tested in two different geological areas. The index takes into account the hydrochemical parameters that exceed the contamination limit. Their study concluded that the pollution index is well suited to classifying water quality and cartographic representation. Soltan (1999) used the water quality index to calculate the water quality of the artesian wells in the Dakhla oasis, which is calculated using nine parameters. Stigter et al. (2006) conducted groundwater quality studies in Portugal. According to the water quality index, groundwater shows a high level of contamination due to agricultural activity. Boateng et al. (2016) evaluated the hydrochemical characteristics and quality of groundwater in the Ejisu-Juaben Municipality, Ghana, based on different indices, which revealed that the majority of the samples fall in the good to excellent category, suggesting that the groundwater is suitable for drinking and other domestic uses. Water quality indices have also been identified as excellent tools for evaluation and communication in agroenvironmental policy (Alobaidy et al. 2010; Abbasnia et al. 2019; Khalid 2019; Solangi et al. 2019; Zhou et al. 2020). Adimalla et al. (2018) investigated the groundwater in Telangana for drinking and irrigation purposes. They found that, according to the water quality index, $90 \%$ of groundwater samples in the study region were well suited for irrigation. Thus, various water quality indices play an important role in water quality assessment, but they are not suitable for a detailed analysis and evaluation of the relationship between physical and chemical parameters.

In rural built-up areas, sewage disposal and landfill sites, as well as sewage and septic tanks, are considered one of the largest sources of pollutant discharge to the environment, which remains an unsolved problem not only in less-developed areas of the world but also in developed areas, as well (Reay 2004; Szabó et al. 2016; Mester et al. 2017; 
Schuler et al. 2019). In the countries of easterncentral Europe, due to inadequate sewage management and the lack of wastewater treatment systems, sewage infiltration into the groundwater is a crucial issue (Devic et al. 2014; Bugajski et al. 2019; Mester et al. 2019; Janža et al. 2020). As a consequence of this, the groundwater quality has significantly decreased in these areas (Balla et al. 2020).

With its accession to the European Union in 2004, Hungary ratified the Water Framework Directive (2000/60/EC) and the Urban Wastewater Treatment Directive (271/91/EEC) which regulate the issue of contamination originating from agriculture and domestic wastewater. The latter requires the establishment of a sewage system in every settlement with a population over 2000. The establishment of the sewage system in Hungary has accelerated over recent years. While in $200431.5 \%$ of the households with a public water supply system were not connected to the sewage system, this ratio decreased to $13.3 \%$ in 2018 (HCSO 2019). In the Northern Great Plain region-where the settlement investigated is located-this ratio was $14.7 \%$. In the settlement under investigation, the operative works started in 2013, and the sewage system was completed in 2014. In 2017, more than $90 \%$ of households were connected to the sewage system; however, there were still households which had not fulfilled the legal requirements.

Although significant progress has been made in the construction of municipal sewerage networks in many countries around the world, no studies have been conducted that have shown changes in water quality in the post-sewerage period. Presumably, this may be due to the fact that these types of studies require several years of monitoring and it is absolutely necessary to assess the baseline condition from the period before sewerage. However, the vast majority of settlements do not have such a database covering the whole settlement. It is a well-known fact that the construction of a sewerage network is an extremely costly investment, and it can be justifiably expected that there be an accurate picture of the positive effects of the investment. In our study, we examined this issue using three water quality indices, during which we compared the quality of the groundwater resources of the settlement examined in the presewerage period with the water quality of the postsewerage period.

Before performing the measurements, the following hypotheses were made:
1 As a result of the decades-long wastewater effluent from the uninsulated sewage tanks, the quality of the settlement's groundwater resources has deteriorated sharply, which will be detectable on the basis of all three indices.

2 In the post-sewerage period, there will be positive changes in water quality, which will also be reflected in a positive change in the pollution categories of the various indices.

3 We hypothesized that despite the same input data, there would be differences in the categorization of each water sample for different indices, but they would correlate with each other for the entire database.

\section{Material and Methods}

\subsection{Site Location and Characteristics}

The settlement under investigation-Báránd - is located in the eastern part of the Great Hungarian Plain, in the Nagy-Sárrét region on the western part of the alluvial deposit of the Sebes-Körös River (Fig. 1), and has a population of 2611 (HSCO 2019). The altitude of the Nagy-Sárrét is typically $85-89 \mathrm{~m}$, and the region is classified as a flat plain (relative relief $0-3 \mathrm{~m} / \mathrm{km}^{2}$ ). The groundwater level can be found close to the surface, at a depth of 1-2 m; consequently, all the soil types have been formed under the influence of water (Michéli et al. 2006). In the study area, the most frequent soil types are Solonetz, Vertisol, Kastenozem, and Chernozem, and in the built-up area - as a result of anthropogenic effectsTechnosol (Balla et al. 2016).

\subsection{Field Sampling and Laboratory Analysis}

In this study, we performed an analysis of the water samples collected during the summers of 2013, 2017, and 2018. The most characteristic pollutants of municipal wastewater were included in the analysis. Analytical measurements were carried out in the Geography Laboratory of the University of Debrecen. The $\mathrm{pH}$ and EC values were determined using a WTW 315 i measuring instrument, the $\mathrm{NH}_{4}{ }^{+}$concentrations were determined with Nessler reagent (HS ISO 7150-1:1992), the $\mathrm{NO}_{2}{ }^{-}$concentrations were determined with alfaNaftil-amin (HS 448-18:2009), and the $\mathrm{NO}_{3}{ }^{-}$ 


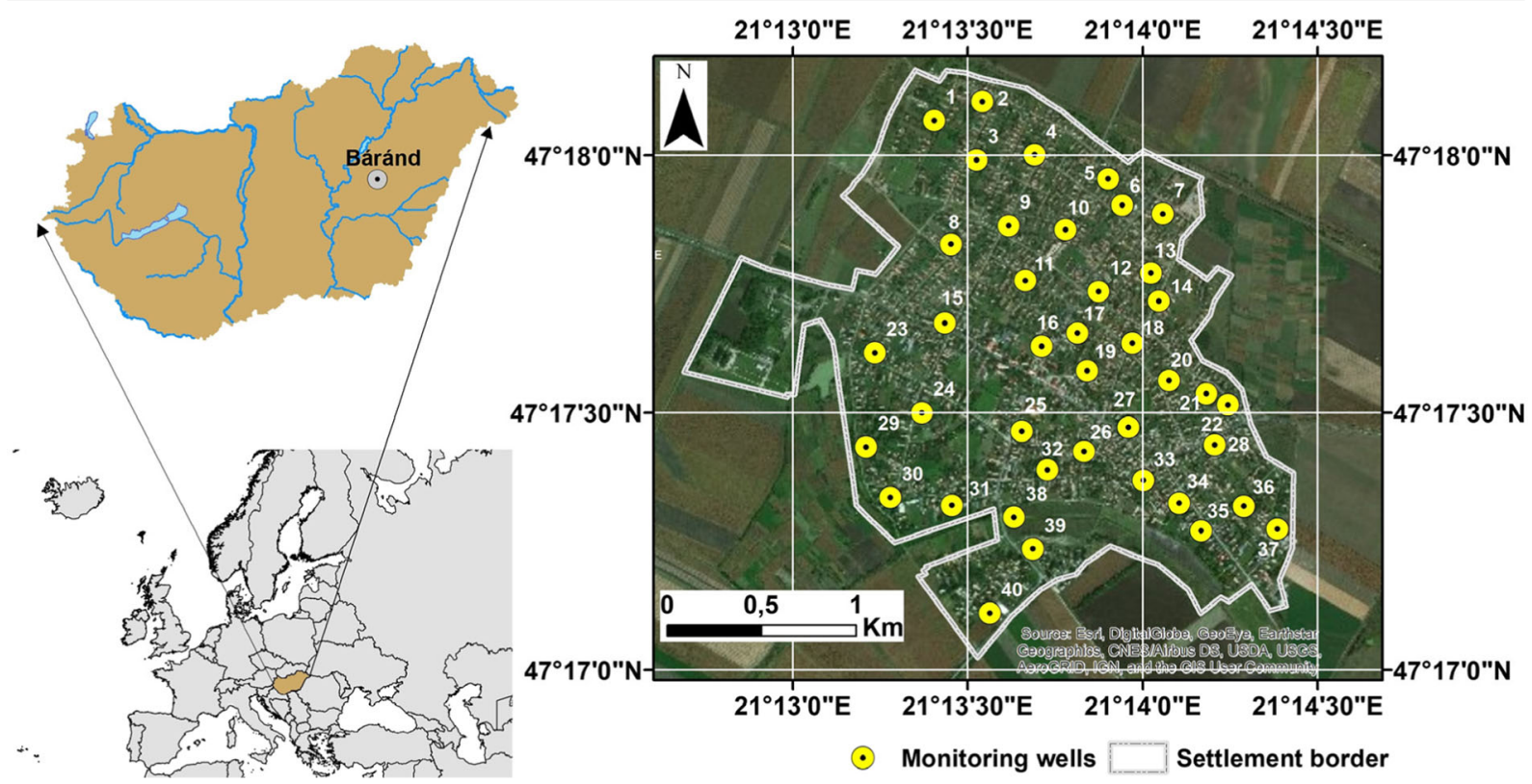

Fig. 1 Location of the investigated settlement in Hungary

concentrations were determined with sodium-salicylate (HS 1484-13:2009) using a spectrophotometer. The $\mathrm{PO}_{4}{ }^{3-}$ concentrations were determined according to Hungarian Standard HS 12750-17: 1974, using a spectrophotometer. The CODps value was determined with potassium-permanganate, and $\mathrm{Na}^{+}$was measured by PerkinElmer 3110 AAS.

\subsection{Calculation of Water Quality Indices}

\subsubsection{The Water Quality Index Developed by Rapant et al. (1995)}

The index reflects the combined effect of parameters harmful to groundwater, taking into account all parameters above the limit value. The index can therefore be considered the sum of the polluting factors. When determining the degree of contamination (Backman et al. 1998), calculations should be performed for each water sample. The calculations were performed according to the following equation:

$C_{d}=\sum_{i=1}^{n} C_{f i}$ where : $C_{f i}=\frac{C_{A i}}{C_{N i}}-1$

$\boldsymbol{C}_{\boldsymbol{f} i}=$ contamination factor for the $i$ th component, $C_{A i}=$ analytical value of the $i$ th component, and $\boldsymbol{C}_{N i}=$ upper permissible concentration of the $i$ th component. The contamination index values were divided into 5 categories (the originally 4 categories with the excellent category have been expanded for comparability with other indices), which are summarized in Table 1.

\subsubsection{The Weighted Water Quality Index by Brown et al. (1970) and the Water Quality Status Calculated from It}

Since the importance of different parameters depends on the use of a given water, Brown et al. (1970) proposed the use of a weighted arithmetic index, the calculation of which consists of the following steps:

$\mathrm{WQI}=\sum Q_{n} W_{n} / \sum W_{n}$

where $Q_{n}$ is the quality rating of the $n$th water quality parameter, and $W_{n}$ is the unit weight of the $n$th water quality parameter. The quality rating $Q_{n}$ is calculated using the equation:

$Q_{n}=100\left[\left(V_{n}-V_{i}\right) /\left(V_{s}-V_{i}\right)\right]$

Table 1 Index values and their categories

\begin{tabular}{ll}
\hline $\mathrm{C}_{\mathrm{d}}$ value & Degree of contamination \\
\hline 0 & Excellent \\
$0<$ and $<1$ & Low \\
$1-2$ & Medium \\
$2-3$ & High \\
$>3$ & Very high \\
\hline
\end{tabular}


Table 2 WQI range, WQS, and possible usage of the water sample (Brown et al. 1970)

\begin{tabular}{lll}
\hline WQI & Water quality status (WQS) & Possible usage \\
\hline $0-25$ & Excellent water quality & Drinking, irrigation, and industrial \\
$26-50$ & Good water quality & Irrigation and industrial \\
$51-75$ & Poor water quality & Irrigation and industrial \\
$76-100$ & Very poor water quality & Irrigation \\
Above 100 & Unsuitable for any usage & Proper treatment required before use \\
\hline
\end{tabular}

where $V_{n}$ is the actual amount of the $n$th parameter present, $V_{i}$ is the ideal value of the parameter $\left(V_{i}=0\right.$, except for $\left.\mathrm{pH}\left(V_{i}=7\right)\right)$, and $V_{s}$ is the standard permissible value for the $n$th water quality parameter. The unit weight $\left(W_{n}\right)$ is calculated using the formula:

$W_{n}=k / V_{s}$

where $k$ is the constant of proportionality and is calculated using the equation:

$k=\left[1 / \sum 1 / V_{s}=1,2, \ldots, n\right]$

The water quality status (WQS) according to the WQI is shown in Table 2.

\subsubsection{Calculation of the CCME Water Quality Index}

This is a rating system developed by the Canadian Council of Ministers of the Environment in 2001. The ranking system is based on a combination of three factors:

F1: Number of parameters tested that exceed the contamination limit (scope).

$$
\mathrm{F} 1=\left(\frac{\text { number of failed parameters }}{\text { total number of parameters }}\right) \times 100
$$

F2: The percentage of failed tests (frequency).

$$
\mathrm{F} 2=\left(\frac{\text { number of failed tests }}{\text { total number of tests }}\right) \times 100
$$

F3: The amount by which failed test values do not meet their objectives (amplitude). Factor 3 can be calculated in three steps:

$$
\begin{aligned}
\text { excursion }_{i} & =\left(\frac{\text { failed test value }_{i}}{\text { Objective }_{j}}\right)-1 \\
\mathrm{nse} & =\frac{\sum_{i=1}^{n} \text { excursion }_{i}}{0.01 \mathrm{nse}+0.01} \\
\mathrm{~F} 3 & =\frac{\mathrm{nse}}{0.1 \mathrm{nse}+0.01}
\end{aligned}
$$

After calculating all the three factors, the WQI can be determined by the following equation:

$\mathrm{CCME} \mathrm{WQI}=100-\left(\frac{\sqrt{\mathrm{F} 1^{2}}+\mathrm{F} 2^{2}+\mathrm{F}^{2}}{1.732}\right)$

The factor value of 1.732 is introduced to a scale index ranging from 0 to 100 , where 0 is the "worst" and 100 is the "best" WQI value (Table 3).

Table $3 \mathrm{CCME}_{\mathrm{wqi}}$ values and their ratings

\begin{tabular}{lll}
\hline WQI & $\mathrm{CCME}_{\mathrm{wqi}}$ value & Description of the water quality \\
\hline Excellent & $95-100$ & Conditions very close to natural or pristine levels. \\
Good & $80-94$ & Rarely depart from natural or desirable levels. \\
Fair & $65-79$ & Conditions sometimes depart from natural or desirable levels. \\
Marginal & $45-64$ & Conditions often depart from natural or desirable levels. \\
Poor & $0-44$ & Conditions usually depart from natural or desirable levels. \\
\hline
\end{tabular}


Table 4 Categorization of water samples based on water quality indices

\begin{tabular}{|c|c|c|c|c|c|c|c|c|c|c|c|c|}
\hline \multirow[t]{2}{*}{ Rank } & \multicolumn{3}{|l|}{2013} & \multicolumn{3}{|l|}{2017} & \multicolumn{3}{|l|}{2018} & \multicolumn{3}{|l|}{2019} \\
\hline & WQS & $\mathrm{C}_{\mathrm{d}}$ & $\mathrm{CCME}_{\mathrm{wqi}}$ & WQS & $\mathrm{C}_{\mathrm{d}}$ & $\mathrm{CCME}_{\mathrm{wqi}}$ & WQS & $\mathrm{C}_{\mathrm{d}}$ & $\mathrm{CCME}_{\mathrm{wqi}}$ & WQS & $\mathrm{C}_{\mathrm{d}}$ & $\mathrm{CCME}_{\mathrm{wqi}}$ \\
\hline 1 & 0 & 0 & 0 & 0 & 1 & 1 & 0 & 1 & 1 & 1 & 1 & 1 \\
\hline 2 & 0 & 3 & 3 & 12 & 6 & 5 & 5 & 6 & 4 & 11 & 4 & 6 \\
\hline 3 & 4 & 9 & 5 & 14 & 13 & 12 & 11 & 12 & 11 & 9 & 14 & 13 \\
\hline 4 & 8 & 10 & 17 & 5 & 9 & 13 & 12 & 11 & 15 & 6 & 8 & 8 \\
\hline 5 & 28 & 18 & 15 & 9 & 11 & 9 & 12 & 10 & 9 & 13 & 13 & 12 \\
\hline Total & 40 & 40 & 40 & 40 & 40 & 40 & 40 & 40 & 40 & 40 & 40 & 40 \\
\hline
\end{tabular}
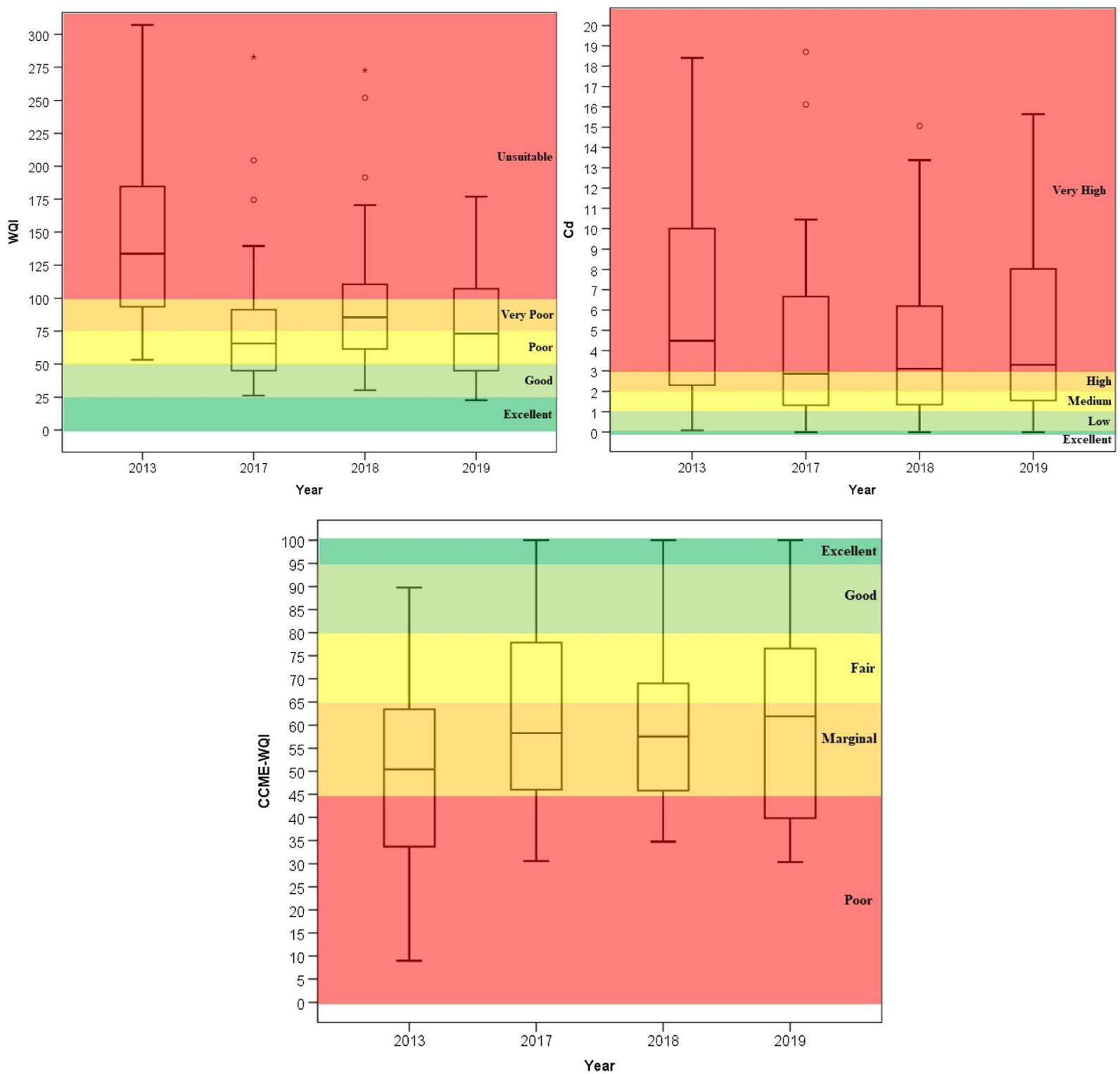

Fig. 2 CCME $_{\text {wqi }}$ values in the years before (2013) and after sewerage $(2017,2018,2019)$ 
Table 5 Descriptive statistics of index values

\begin{tabular}{lllll}
\hline Index/year & Mean & Minimum & Maximum & St. dev. \\
\hline WQI/2013 & 156.76 & 53.10 & 541.87 & 94.05 \\
$\mathrm{WQI} / 2017$ & 78.89 & 26.20 & 282.74 & 51.76 \\
$\mathrm{WQI} / 2018$ & 103.33 & 30.31 & 403.79 & 72.12 \\
$\mathrm{WQI} / 2019$ & 87.16 & 22.74 & 368.11 & 61.23 \\
$\mathrm{C}_{\mathrm{d}} / 2013$ & 6.41 & 0.07 & 18.4 & 4.89 \\
$\mathrm{C}_{\mathrm{d}} / 2017$ & 4.75 & 0.00 & 26.40 & 5.48 \\
$\mathrm{C}_{\mathrm{d}} / 2018$ & 4.34 & 0.00 & 15.06 & 3.97 \\
$\mathrm{C}_{\mathrm{d}} / 2019$ & 5.38 & 0.00 & 21.31 & 5.06 \\
$\mathrm{CCME}_{\mathrm{wqi}} / 2013$ & 50.17 & 8.97 & 89.78 & 19.96 \\
$\mathrm{CCME}_{\mathrm{wqi}} / 2017$ & 61.35 & 30.58 & 100.00 & 19.67 \\
$\mathrm{CCME}_{\mathrm{wqi}} / 2018$ & 59.97 & 34.73 & 100.00 & 16.88 \\
$\mathrm{CCME}_{\mathrm{wqi}} / 2019$ & 59.55 & 30.36 & 100.00 & 19.87 \\
\hline
\end{tabular}

\section{Results and Discussion}

3.1 Categorization of Water Samples Based on Water Quality Indices

Water samples collected before (2013) and after (2017, $2018,2019)$ the establishment of a sewerage were rated on a scale of 1 to 5 based on their quality, with 1 being the best and 5 the worst rating. The results of the ranking are shown in Table 4.

For the 2013 pre-sewerage sampling, no water sample was included in category 1 "excellent," 3 samples
Table 7 Differences between categories pre- and post-sewerage

Test statistics ${ }^{\mathrm{a}}$

\begin{tabular}{|c|c|c|c|}
\hline & $\begin{array}{l}\text { WQS_after } \\
\text { sewerage- } \\
\text { WQS_before } \\
\text { sewerage }\end{array}$ & $\begin{array}{l}\mathrm{C}_{\mathrm{d} \_ \text {after }} \\
\text { sewerage-- } \\
\mathrm{C}_{\mathrm{d} \_ \text {before }} \\
\text { sewerage }\end{array}$ & $\begin{array}{l}\mathrm{CCME}_{\text {wqi_after }} \\
\text { sewerage- } \\
\mathrm{CCME}_{\text {wqi_before }} \\
\text { sewerage }\end{array}$ \\
\hline$Z$ & $-4.541^{b}$ & $-2.548^{\mathrm{b}}$ & $-2.683^{b}$ \\
\hline $\begin{array}{l}\text { Asymp. } \\
\text { Sig. } \\
(2- \\
-- \\
\text { tailed) }\end{array}$ & 0.000 & 0.011 & 0.007 \\
\hline
\end{tabular}

were included in category 2 "good" for both the $\mathrm{C}_{\mathrm{d}}$ and the $\mathrm{CCME}_{\mathrm{wqi}}$, and no water sample was included in category 2 according to the WQS. The strong pollution of the settlement's groundwater resources is well illustrated by the fact that $90 \%$ of the groundwater wells according to the WQS, 70\% of the wells according to the $\mathrm{C}_{\mathrm{d}}$, and $80 \%$ of the wells according to the $\mathrm{CCME}_{\mathrm{wqi}}$ fall into the 4-5 "polluted-heavily polluted" categories.

Our results showing significant pollution of the water resources of the settlement are consistent with the results of other studies carried out in a rural environment (Adekunle et al. 2007; Khan et al. 2017; Celestino et al. 2019; Muzenda et al. 2019). The results of the

Table 6 Results of discriminant analysis

Classification results ${ }^{\mathrm{a}, \mathrm{c}}$

\begin{tabular}{|c|c|c|c|c|c|}
\hline & & \multirow[t]{2}{*}{ Categories } & \multicolumn{2}{|c|}{ Predicted group membership } & \multirow[t]{2}{*}{ Total } \\
\hline & & & 1 & 2 & \\
\hline \multirow[t]{4}{*}{ Original } & Count & Before sewerage (1) & 8 & 32 & 40 \\
\hline & & After sewerage (2) & 6 & 114 & 120 \\
\hline & $\%$ & Before sewerage (1) & 20.0 & 80.0 & 100.0 \\
\hline & & After sewerage (2) & 5.0 & 95.0 & 100.0 \\
\hline \multirow[t]{4}{*}{ Cross-validated $^{\mathrm{b}}$} & Count & Before sewerage (1) & 8 & 32 & 40 \\
\hline & & After sewerage (2) & 7 & 113 & 120 \\
\hline & $\%$ & Before sewerage (1) & 20.0 & 80.0 & 100.0 \\
\hline & & After sewerage (2) & 5.8 & 94.2 & 100.0 \\
\hline
\end{tabular}

a $76.3 \%$ of original grouped cases correctly classified

${ }^{\mathrm{b}}$ Cross-validation is done only for those cases in the analysis. In cross-validation, each case is classified by the functions derived from all cases other than that case

c $75.6 \%$ of cross-validated grouped cases correctly classified 
pre-sewerage sampling support our hypothesis that heavily polluted groundwater is also expressed on the basis of the indices applied; however, we did not expect that the WQS would place an average of $30 \%$ more wells in the worst category 5 than the other two indices.

In 2017, 3 years after the establishment of the sewerage, significant changes can be observed. For all three indices, the number of wells in category 5 indicating the most contaminated samples decreased significantly, while the number of samples in categories 2 (good) and 3 (acceptable) increased. For the WQS, the number of wells in the two categories increased from 4 to 26 , for the $\mathrm{C}_{\mathrm{d}}$ from 12 to 19 , and for the $\mathrm{CCME}_{\mathrm{wqi}}$ from 8 to 17 in the two categories $(2,3)$ compared to the reference year. Both the $\mathrm{C}_{\mathrm{d}}$ and $\mathrm{CCME}_{\mathrm{wqi}}$ had one well classified as excellent.

In the next year, no significant change was detected based on the $\mathrm{C}_{\mathrm{d}}$ and the $\mathrm{CCME}_{\mathrm{wqi}}$. However, in the case of the WQS, the number of wells in category 2 decreased significantly, while in category 4 , we saw an increase. The most significant change in 2019 compared to 2018 is that the number of wells in category 4 decreased for all three indices, while the number of wells in category 5 increased. However, their number still lags behind the pre-sewerage situation. The number of wells in categories $2-3$ is around $50 \%$ for all three indices, compared to $10-30 \%$ in 2013 .

To obtain a more detailed picture of the degree of contamination, we plotted the index values of each well on a boxplot diagram (Fig. 2).

For the WQS and $\mathrm{C}_{\mathrm{d}}$ indices, a lower value indicates better water quality, while for the $\mathrm{CCME}_{\mathrm{wqi}}$, a higher value on the hundred scale indicates better water quality.

Changes in the mean, minimum, and maximum values of all three indices indicate positive changes in water quality (Table 5). For the WQI, the pre-sewerage average of 156.76 decreased to 87.16 by 2019 . For the $\mathrm{CCME}_{\mathrm{wqi}}$, the average rose from 50.17 to 59.55 , an increase of nearly $10 \%$. The maximum value in the year following the establishment of the sewerage is 100 , which shows that no limit value was exceeded for any of the examined parameters.

In order to determine whether the results before and after the sewerage can be separated, the results were

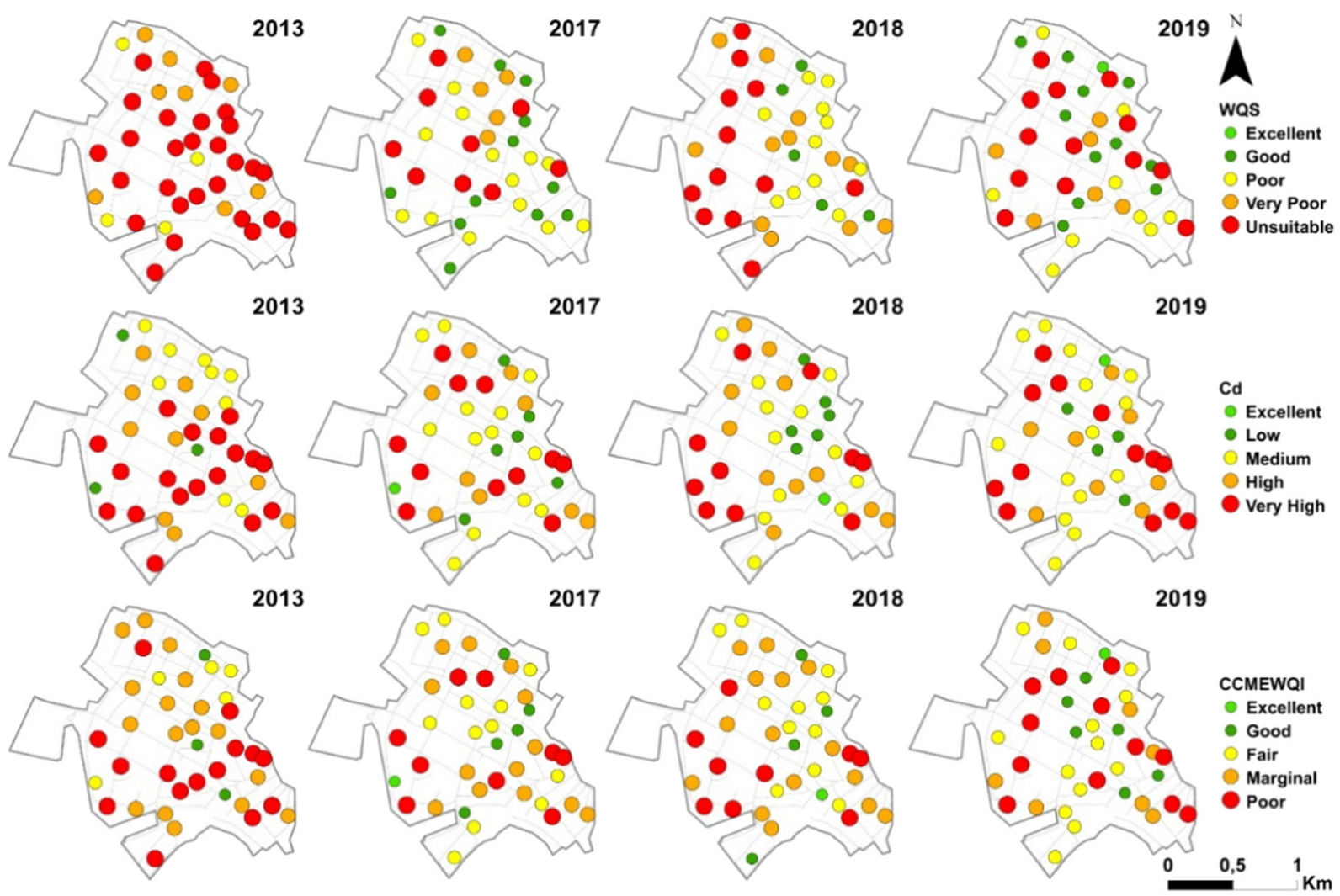

Fig. 3 Spatial distribution of water quality indices in the years before $(2013)$ and after sewerage $(2017,2018,2019)$ 
subjected to discriminant analysis. The Wilks-Lambda test showed a significant value $(p=0.000)$. A total of $75.6 \%$ of the cross-validated values were successfully categorized into the appropriate category (Table 6). The correct classification of more than two-thirds of the samples indicates a significant difference between pre- and post-sewerage. The difference between the two periods for the different indices was assessed by using the Wilcoxon test (Table 7). Based on the results, it can be concluded that after the establishment of the sewerage system, the WQI values of the groundwater wells did not improve by accident; the reason for the improvement was the significant reduction in wastewater discharge.

The positive changes in water quality observed in the years following the sewerage could clearly be traced back to the cessation of wastewater outflow. The results support our hypothesis 2 , according to which changes in individual hydrochemical parameters resulted in a positive shift in the water quality category of most of the wells.

\subsection{Spatial and Temporal Distribution/Variation of Groundwater Quality}

In order to explore and illustrate the spatial distribution of the degree of contamination (which is one of the advantages of the indices), the values for each well were also plotted on thematic maps (Fig. 3). We assigned a color code to each of the 5 categories established. Because a large number of samples were available, we also generated interpolated maps of the extent of contamination (Fig. 4).

Based on the thematic maps, it can be stated that in 2013, all three indices showed the highest pollution in the inner and southern parts of the settlement, while the northern areas of the settlement were less polluted. The main differences were in the extent of the heavily contaminated areas (WQS vs. $\mathrm{C}_{\mathrm{d}}-\mathrm{CCME}_{\mathrm{wqi}}$ ).

In 2017, the proportion of the most contaminated areas marked with a red color code decreased significantly. In the inner areas of the settlement, the degree of pollution decreased from levels 4-5 to levels 3-4. In the case of all three indices, the "good" water quality status appeared in varying degrees in the north-central and southern areas of the settlement as well. The extent of these areas was the largest in the case of the WQS, while a smaller extent was observed in the case of the $\mathrm{C}_{\mathrm{d}}$ and $\mathrm{CCME}_{\mathrm{wqi}}$. The most significant difference compared to the WQS is in the SE part of the settlement. For the $C_{d}$ and $\mathrm{CCME}_{\mathrm{wqi}}$ indices, a very similar picture emerges in all the 4 years studied.
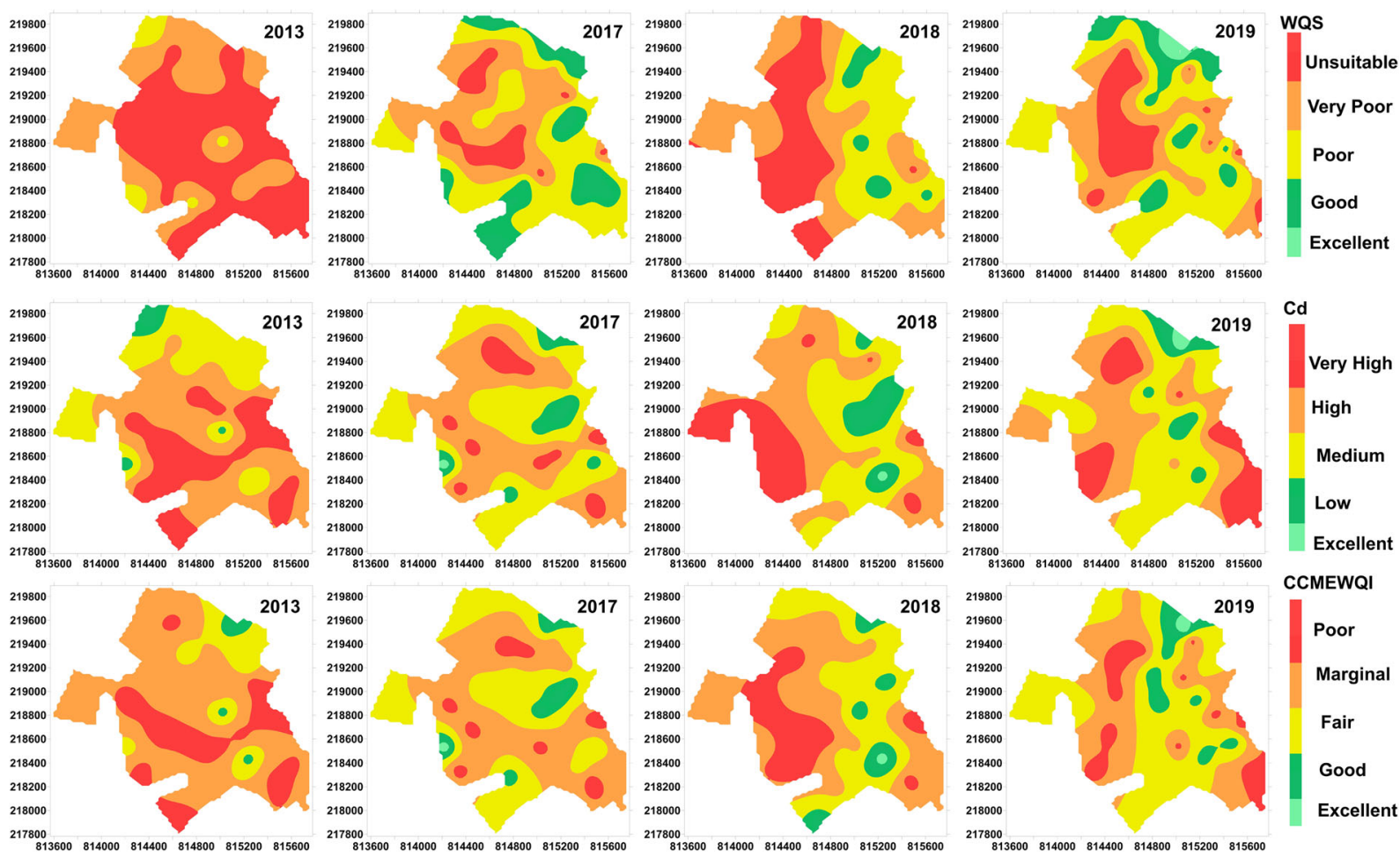

Fig. 4 Spatial distribution of water quality indices in the years before $(2013)$ and after sewerage $(2017,2018,2019)$ 
In 2018, the western part of the settlement can be considered heavily polluted again, on the basis of all three indices; however, the central and eastern parts showed significantly lower pollution (medium and good) for all three indices. In 2019, compared to 2018, an improvement in water quality can be observed; typically, we have shown the purification of the western areas. The extent of the low-pollution, north-south zone passing through the settlement area increased in the case of all three indices.

\subsection{Comparison of the Water Quality Indices Applied}

To determine the strength of the relationship between the indices, correlation studies were performed (Table 8). Based on the results, we found that there is a significant $(p>0.01)$ relationship between all three indices. The weakest relationship was between the $C_{d}$ and the WQS $(r=0.552)$, while the strongest relationship ( $r=0.853$ ) was between the $\mathrm{CCME}_{\mathrm{wqi}}$ and the $\mathrm{C}_{\mathrm{d}}$. The $\mathrm{CCME}_{\mathrm{wqi}}-\mathrm{C}_{\mathrm{d}}$ matrix was also plotted on a scatter plot diagram (Fig. 5). The numbers at the points show the number of wells in the same category.

Correlation is significant at the 0.01 level

After categorizing the water samples, we calculated how differently the indices categorize the same sample (Table 9). During the study, we did not separate the data for 4 years, they were treated as one data set. The results show that the difference between the indices is - in the vast majority of cases - a maximum of \pm 2 on a fivepoint scale. Of the 160 cases, in only 4 cases was the difference \pm 3 . In the case of the WQS- $\mathrm{C}_{\mathrm{d}}$, a difference of $-1.0,+1$ was detected in $81.6 \%$ of the cases. The equivalent figures for the WQS-CCME $\mathrm{wqi}_{\mathrm{w}}$ and the $\mathrm{CCME}_{\mathrm{wq} i}-\mathrm{C}_{\mathrm{d}}$ are $85.8 \%$ and $99.2 \%$, respectively. In the case of the $\mathrm{CCME}_{\mathrm{wqi}}-\mathrm{C}_{\mathrm{d}}, 72.5 \%$ of the wells fell into the same category.

Based on the above, it can be stated that according to our hypothesis 3 , despite the same input data, different water quality indices classified some of the samples into

Table 8 Correlation matrix of water quality indices based on 4year data

\begin{tabular}{llll}
\hline Correlation & WQS & $\mathrm{C}_{\mathrm{d}}$ & $\mathrm{CCME}_{\text {wqi }}$ \\
\hline WQS & 1 & & \\
$\mathrm{C}_{\mathrm{d}}$ & 0.552 & 1 & 1 \\
$\mathrm{CCME}_{\text {wqi }}$ & 0.565 & 0.853 & 1 \\
\hline
\end{tabular}

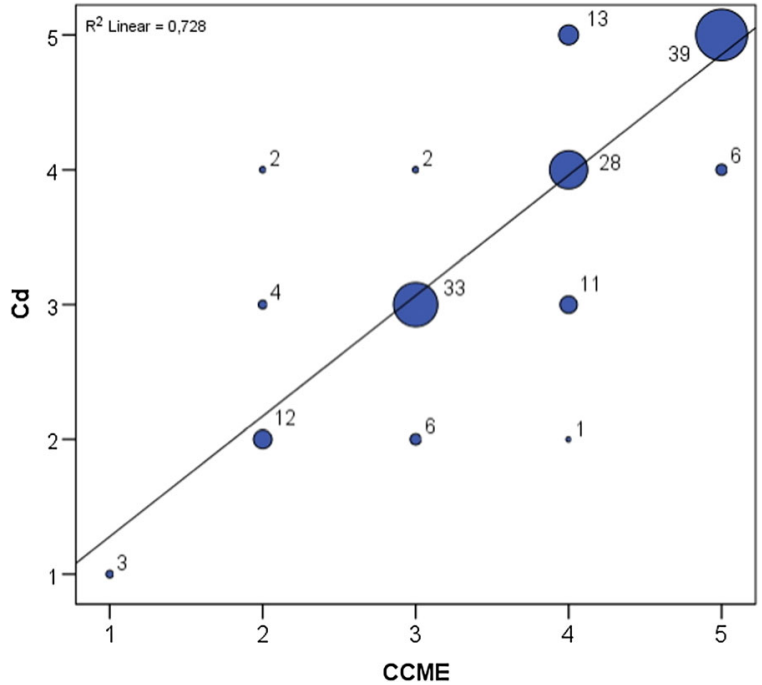

Fig. 5 Scatter plot diagram for $\mathrm{C}_{\mathrm{d}}$ vs. $\mathrm{CCME}_{\mathrm{wqi}}$ categories

different categories. Although a significant relationship was found between the categories created by the water quality indices applied (Table 8), significant differences in the strength of the relationship were found.

In order to determine the reasons for the differences as accurately as possible, we prepared the difference value maps of the indices (Fig. 6). Areas where both indices classified the sample in the same category were marked in white. The smallest difference for the $\mathrm{CCME}_{\mathrm{wqi}}-\mathrm{C}_{\mathrm{d}}$ was detected in 2017. In the case of the WQS- $C_{d}$, in 2013, the WQS values in the northern part of the settlement were + $1+2$ more polluted than the $C_{d}$ values; however, in 2017, the WQS values in the SE part of the settlement were - 12 lower, than the $C_{d}$ values. A similar pattern emerges for

Table 9 Differences between categories for 4 years

\begin{tabular}{llll}
\hline Difference & $\begin{array}{l}\text { WQS-C } \\
\text { Number of wells }\end{array}$ & $\begin{array}{l}\text { WQS-CCME } \\
\text { Number } \\
\text { of wells }\end{array}$ & $\begin{array}{l}\mathrm{C}_{\mathrm{d}}-\mathrm{CCME}_{\mathrm{wqi}} \\
\text { of wells }\end{array}$ \\
\hline 0 & 70 & 71 & 115 \\
1 & 40 & 37 & 19 \\
-1 & 21 & 30 & 23 \\
2 & 12 & 7 & 2 \\
-2 & 16 & 12 & 1 \\
3 & 0 & 3 & 0 \\
-3 & 1 & 0 & 0 \\
4 & 0 & 0 & 0 \\
-4 & 0 & 0 & 0 \\
Total & 160 & 160 & 160 \\
\hline
\end{tabular}




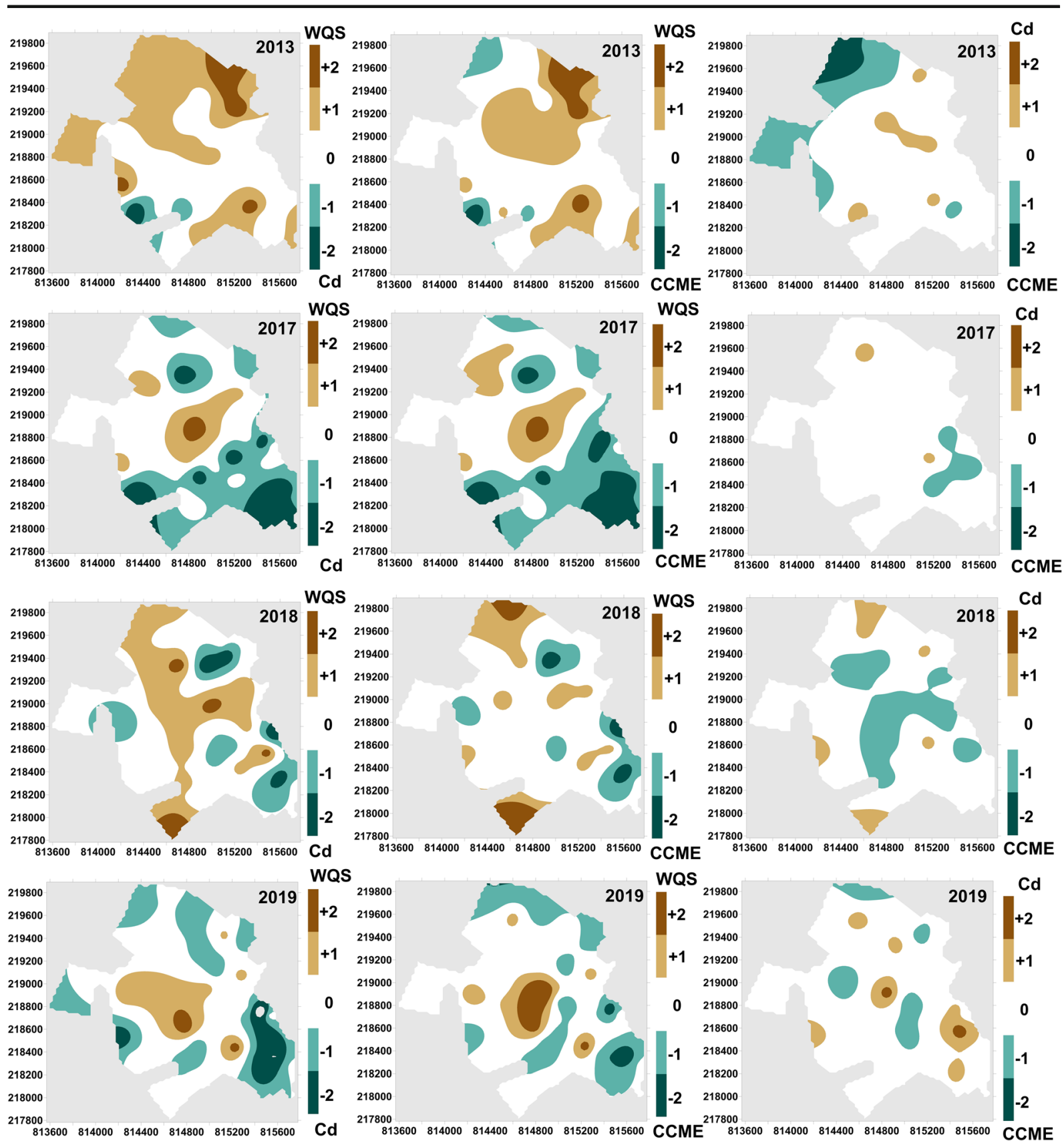

Fig. 6 Difference value maps of the indices

the WQS-CCME ${ }_{\mathrm{wqi}}$. The differences are due to the different weighting of the WQS index, as a result of which the index responds more sensitively to changes in ammonium and phosphate values. The other factor is that the WQS is less sensitive to nitrate changes, which are given more weight in the other two indices $\left(\mathrm{C}_{\mathrm{d}}, \mathrm{CCME}_{\mathrm{wqi}}\right)$. Another influencing factor is that the $\mathrm{C}_{\mathrm{d}}$ index does not take into account parameters below the limit, even if they are very close to it, while the WQS and $\mathrm{CCME}_{\mathrm{wqi}}$ take these into account.

\section{Conclusions}

In the present study, the groundwater quality changes of a settlement were evaluated after the construction of its 
sewerage network using different water quality indices. The focus of our research was on how different indices categorize water samples based on the same input data and how well they are suitable for accurately expressing changes in water quality.

The strong pollution of the settlement's groundwater before the establishment of the sewerage (2013) is well illustrated by the fact that $90 \%$ of the groundwater wells according to the WQS, $70 \%$ of the wells according to the $\mathrm{C}_{\mathrm{d}}$, and $80 \%$ of the wells according to the $\mathrm{CCME}_{\mathrm{wqi}}$ fall into the 4-5 "polluted-heavily polluted" categories. After the establishment of the sewerage (2017, 2018, 2019), significant changes can be observed. For all three indices, the number of wells in category 5 indicating the most contaminated samples decreased significantly, while the number of samples in categories 2 (good) and 3 (acceptable) increased.

Significant correlations between all three indices were found, but the strongest $(r=0.853)$ was between the $\mathrm{CCME}_{\mathrm{wqi}}$ and the $\mathrm{C}_{\mathrm{d}}$ indices. The two indices classified $71.9 \%$ of the wells in the same category on a fivepoint scale and $98.1 \%$ of the wells with a difference of a maximum of $+1-1$.

Based on the indices, pollution maps of the settlement were created. In the period before sewerage, based on all three indices, the central and southern areas were the most polluted, the difference was only in the extent of the contaminated area. In the case of the measurements following the establishment of the sewerage, all three indices showed the purification of the central and southern areas. Based on the result, it can be stated that all three indices adequately reflect the status of pollution, well reflecting positive changes in water quality.

It was determined that the differences observed between the indices are due to the different weighting of the WQS index, as a result of which, the index responds more sensitively to changes in ammonium and phosphate values. The other factor is that the WQS is less sensitive to nitrate changes, which is given more weight in the other two indices $\left(\mathrm{C}_{\mathrm{d}}, \mathrm{CCME}_{\mathrm{wqi}}\right)$. Another influencing factor is that the $\mathrm{C}_{\mathrm{d}}$ index does not take into account parameters below the limit, even if they are very close to it, while the WQS and the $\mathrm{CCME}_{\mathrm{wqi}}$ take this into account.

It is important to mention that when applying indices, the parameters that are expected to be important should not be excluded from the calculation of the indices. Accordingly, other parameters should be considered when assessing the status of an agricultural, industrial, or urban environment.
With the help of the indices, we determined that the process of groundwater purification in the settlement has started, although it will continue for years to come. Maps created on the basis of indices can help to illustrate purification processes more easily, which can be very profitably used to support further environmental measures.

Funding Open access funding provided by University of Debrecen. The research was financed by the Higher Education Institutional Excellence Programme (NKFIH-1150-6/2019) of the Ministry of Innovation and Technology in Hungary, within the framework of the 4th thematic programme of the University of Debrecen.

This work was supported by the construction EFOP-3.6.3VEKOP-16-2017-00002. The project was supported by the European Union, co-financed by the European Social Fund.

\section{Compliance with Ethical Standards}

Conflict of Interest The authors declare that they have no conflict of interest.

Open Access This article is licensed under a Creative Commons Attribution 4.0 International License, which permits use, sharing, adaptation, distribution and reproduction in any medium or format, as long as you give appropriate credit to the original author(s) and the source, provide a link to the Creative Commons licence, and indicate if changes were made. The images or other third party material in this article are included in the article's Creative Commons licence, unless indicated otherwise in a credit line to the material. If material is not included in the article's Creative Commons licence and your intended use is not permitted by statutory regulation or exceeds the permitted use, you will need to obtain permission directly from the copyright holder. To view a copy of this licence, visit http://creativecommons.org/licenses/by/4.0/.

\section{References}

Abbasi, S. A. (2002). Water quality indices, state of the art report, National Institute of Hydrology, scientific contribution no. incoh/sar-25/2002 (pp. 73-200). Roorkee: INCOH.

Abbasnia, A., Yousefi, N., Mahvi, A. H., Nabizadeh, R., Radfard, M., Yousefi, M., \& Alimohammadi, M. (2019). Evaluation of groundwater quality using water quality index and its suitability for assessing water for drinking and irrigation purposes: case study of Sistan and Baluchistan province (Iran). Human and Ecological Risk Assessment: An International Journal, 25(4), 988-1005.

Adekunle, I. M., Adetunji, M. T., Gbadebo, A. M., \& Banjoko, O. B. (2007). Assessment of groundwater quality in a typical rural settlement in Southwest Nigeria. International Journal 
of Environmental Research and Public Health, 4(4), 307318.

Adimalla, N., Li, P., \& Venkatayogi, S. (2018). Hydrogeochemical evaluation of groundwater quality for drinking and irrigation purposes and integrated interpretation with water quality index studies. Environmental Processes, 5(2), 363-383.

Alobaidy, A. H. M. J., Abid, H. S., \& Maulood, B. K. (2010). Application of water quality index for assessment of Dokan lake ecosystem, Kurdistan region, Iraq. Journal of Water Resource and Protection, 2(09), 792.

Al-Omran, A. M., Mousa, M. A., AlHarbi, M. M., \& Nadeem, M. E. (2018). Hydrogeochemical characterization and groundwater quality assessment in Al-Hasa, Saudi Arabia. Arabian Journal of Geosciences, 11(4), 79.

Backman, B., Bodiš, D., Lahermo, P., Rapant, S., \& Tarvainen, T. (1998). Application of a groundwater contamination index in Finland and Slovakia. Environmental Geology, 36(1-2), 5564.

Balla, D., Novák, T. J., \& Zichar, M. (2016). Approximation of the WRB reference group with the reapplication of archive soil databases. Acta Universitatis Sapientiae, Agriculture and Environment, 8(1), 27-38.

Balla, D., Zichar, M., Tóth, R., Kiss, E., Karancsi, G., \& Mester, T. (2020). Geovisualization techniques of spatial environmental data using different visualization tools. Applied Sciences., 19(10), 6701.

Bilgin, A. (2018). Evaluation of surface water quality by using Canadian Council of Ministers of the Environment Water Quality Index (CCME WQI) method and discriminant analysis method: a case study Coruh River Basin. Environmental Monitoring and Assessment, 190(9), 554.

Boateng, T. K., Opoku, F., Acquaah, S. O., \& Akoto, O. (2016). Groundwater quality assessment using statistical approach and water quality index in Ejisu-Juaben Municipality, Ghana. Environmental Earth Sciences, 75(6), 489.

Bora, M., \& Goswami, D. C. (2017). Water quality assessment in terms of water quality index (WQI): case study of the Kolong River, Assam, India. Applied Water Science, 7(6), 31253135 .

Bouslah, S., Djemili, L., \& Houichi, L. (2017). Water quality index assessment of Koudiat Medouar Reservoir, Northeast Algeria using weighted arithmetic index method. Journal of Water and Land Development, 35(1), 221-228.

Brown, R. M., McClelland, N. I., Deininger, R. A., \& Tozer, R. G. (1970). A water quality index-do we dare? Waterand Sewage Works, 117(1970), 339-343.

Bugajski, P. M., Kurek, K., Młyński, D., \& Operacz, A. (2019). Designed and real hydraulic load of household wastewater treatment plants. Journal of Water and Land Development, 40(1), 155-160.

CCME (2001). Canadian environmental quality guidelines for the protection of aquatic life, CCME water quality index: technical report, 1.0.

Celestino, M. A. E., Ramos Leal, J. A., Martínez Cruz, D. A., Tuxpan Vargas, J., De Lara Bashulto, J., \& Morán Ramírez, J. (2019). Identification of the hydrogeochemical processes and assessment of groundwater quality, using multivariate statistical approaches and water quality index in a wastewater irrigated region. Water, 11(8), 1702.
Debels, P., Figueroa, R., Urrutia, R., Barra, R., \& Niell, X. (2005). Evaluation of water quality in the Chillán River (Central Chile) using physicochemical parameters and a modified water quality index. Environmental Monitoring and Assessment, 110(1-3), 301-322.

Devic, G., Djordjevic, D., \& Sakan, S. (2014). Natural and anthropogenic factors affecting the groundwater quality in Serbia. Science of the Total Environment, 468, 933-942.

Espejo, L., Kretschmer, N., Oyarzún, J., Meza, F., Núñez, J., Maturana, H., ... \& Amezaga, J. (2012). Application of water quality indices and analysis of the surface water quality monitoring network in semiarid north-central Chile. Environmental Monitoring and Assessment, 184(9), 55715588.

Hungarian Central Statistical Office (HSCO) (2019). http:// www.ksh.hu/docs/hun/xstadat/xstadat_eves/i_zrk006b.html

Janža, M., Prestor, J., Pestotnik, S., \& Jamnik, B. (2020). Nitrogen mass balance and pressure impact model applied to an urban aquifer. Water, 12(4), 1171.

Jha, M. K., Shekhar, A., \& Jenifer, M. A. (2020). Assessing groundwater quality for drinking water supply using hybrid fuzzy-GIS-based water quality index. Water Research, 179, 115867.

Kannel, P. R., Lee, S., Lee, Y. S., Kanel, S. R., \& Khan, S. P. (2007). Application of water quality indices and dissolved oxygen as indicators for river water classification and urban impact assessment. Environmental Monitoring and Assessment, 132, 93-110.

Katyal, D. (2011). Water quality indices used for surface water vulnerability assessment. International Journal of Environmental Sciences, 2(1).

Khalid, S. (2019). An assessment of groundwater quality for irrigation and drinking purposes around brick kilns in three districts of Balochistan province, Pakistan, through water quality index and multivariate statistical approaches. Journal of Geochemical Exploration, 197, 14-26.

Khan, F., Husain, T., \& Lumb, A. (2003). Water quality evaluation and trend analysis in selected watersheds of the Atlantic region of Canada. Environmental Monitoring and Assessment, 88(1-3), 221-248.

Khan, A., Khan, H. H., \& Umar, R. (2017). Impact of land-use on groundwater quality: GIS-based study from an alluvial aquifer in the western Ganges basin. Applied Water Science, 7(8), 4593-4603.

Liou, S. M., Lo, S. L., \& Wang, S. H. (2004). A generalized water quality index for Taiwan. Environmental Monitoring and Assessment, 96(1-3), 35-52.

Lumb, A., Halliwell, D., \& Sharma, T. (2006). Application of CCME Water Quality Index to monitor water quality: a case study of the Mackenzie River basin, Canada. Environmental Monitoring and Assessment, 113(1-3), 411-429.

Mester, T., Szabó, G., Bessenyei, É., Karancsi, G., Barkóczi, N., \& Balla, D. (2017). The effects of uninsulated sewage tanks on groundwater. A case study in an eastern Hungarian settlement. Journal of Water and Land Development, 33(1), 123129.

Mester, T., Balla, D., Karancsi, G., Bessenyei, É., \& Szabó, G. (2019). Effects of nitrogen loading from domestic wastewater on groundwater quality. Water SA, 45(3), 349-358.

Michéli, E., Fuchs, M., Hegymegi, P., \& Stefanovits, P. (2006). Classification of the major soils of Hungary and their 
correlation with the World Reference Base for Soil Resources (WRB). Agrokémia és Talajtan, 55(1), 19-28.

Mohamed, A. K., Dan, L., Kai, S., Mohamed, M. A., Aldaw, E., \& Elubid, B. A. (2019). Hydrochemical analysis and fuzzy logic method for evaluation of groundwater quality in the North Chengdu Plain, China. International Journal of Environmental Research and Public Health, 16(3), 302.

Muzenda, F., Masocha, M., \& Misi, S. N. (2019). Groundwater quality assessment using a water quality index and GIS: a case of Ushewokunze Settlement, Harare, Zimbabwe. Physics and Chemistry of the Earth, Parts $A / B / C, 112$, 134-140.

Pesce, S. F., \& Wunderlin, D. A. (2000). Use of water quality indices to verify the impact of Córdoba City (Argentina) on Suquía River. Water research, 34(11), 2915-2926.

Poonam, T., Tanushree, B., \& Sukalyan, C. (2013). Water quality indices important tools for water quality assessment: a review. International Journal of Advances in chemistry, 1(1), $15-28$.

Rapant, S., Vrana, K., \& Bodis, D. (1995). Geochemical atlas of Slovak Republic. Part 1. groundwater (in Slovak) Geofond, Bratislava

Reay, W. G. (2004). Septic tank impacts on ground water quality and nearshore sediment nutrient flux. Groundwater, 42(7), 1079-1089.

Reisenhofer, E., Adami, G., \& Barbieri, P. (1998). Using chemical and physical parameters to define the quality of karstic freshwaters (Timavo River, north-eastern Italy): a chemometric approach. Water Research, 32(4), 1193-1203.

Schuler, M. S., Cañedo-Argüelles, M., Hintz, W. D., Dyack, B., Birk, S., \& Relyea, R. A. (2019). Regulations are needed to protect freshwater ecosystems from salinization. Philosophical Transactions of the Royal Society B, 374(1764), 20180019.

Sharifi, M. (1990). Assessment of surface water quality by an index system in Anzali basin. The Hydrological Basis for Water Resources Management. IAHS Publication, 197, $163-$ 171.

Solangi, G. S., Siyal, A. A., Babar, M. M., \& Siyal, P. (2019). Groundwater quality evaluation using the water quality index (WQI), the synthetic pollution index (SPI), and geospatial tools: a case study of Sujawal district, Pakistan. Human and Ecological Risk Assessment: An International Journal, 26(6), 1529-1549.

Soltan, M. E. (1999). Evaluation of ground water quality in Dakhla Oasis (Egyptian Western Desert). Environmental Monitoring and Assessment, 57(2), 157-168.

Štambuk-Giljanović, N. (1999). Water quality evaluation by index in Dalmatia. Water Research, 33(16), 3423-3440.

Stigter, T. Y., Ribeiro, L., \& Dill, A. C. (2006). Application of a groundwater quality index as an assessment and communication tool in agro-environmental policies-two Portuguese case studies. Journal of Hydrology, 327(3-4), 578-591.

Szabó, G., Bessenyei, É., Hajnal, A., Csige, I., Szabó, G., Tóth, C., Posta, J., \& Mester, T. (2016). The use of sodium to calibrate the transport modeling of water pollution in sandy formations around an uninsulated sewage disposal site. Water, Air, \& Soil Pollution, 227(2), 45.

Tiwari, A. K., Singh, P. K., Singh, A. K., \& De Maio, M. (2016). Estimation of heavy metal contamination in groundwater and development of a heavy metal pollution index by using GIS technique. Bulletin of Environmental Contamination and Toxicology, 96(4), 508-515.

Venkatramanan, S., Chung, S. Y., Selvam, S., Lee, S. Y., \& Elzain, H. E. (2017). Factors controlling groundwater quality in the Yeonjegu District of Busan City, Korea, using the hydrogeochemical processes and fuzzy GIS. Environmental Science and Pollution Research, 24(30), 23679-23693.

Wu, J., Zhang, Y., \& Zhou, H. (2020). Groundwater chemistry and groundwater quality index incorporating health risk weighting in Dingbian County, Ordos basin of Northwest China. Geochemistry, 125607. in Press

Zhou, Y., Li, P., Xue, L., Dong, Z., \& Li, D. (2020). Solute geochemistry and groundwater quality for drinking and irrigation purposes: a case study in Xinle City, North China. Geochemistry, 125609. in Press

Publisher's Note Springer Nature remains neutral with regard to jurisdictional claims in published maps and institutional affiliations. 